BISMA

(Bisnis dan Manajemen)
Volume 14, Issue 1, October 2021, 74-93

ISSN 2549-7790 (Online)

ISSN 1979-7192 (Print)

DOI: $10.26740 /$ bisma.v14n1.p74-93

https://journal.unesa.ac.id/index.php/bisma/index

\title{
Tourism 4.0: digital media communication on online impulse buying and e-satisfaction
}

\author{
Bethani Suryawardani $^{1 *}$, Astri Wulandari ${ }^{2}$, Dandy Marcelino ${ }^{3}$ \\ ${ }^{1,2,3}$ Telkom University, Indonesia
}

\begin{abstract}
The rapid development of ICT changes communication practices and strategies involving government and stakeholder policies in the tourism industry. This is also a challenge and an opportunity for every country in general and tourist destinations to create interesting information on websites and other online media as a promotion. This study aims to find out how digital communication media, especially websites, can influence impulsive buying online and e-satisfaction. The quantitative research approach used surveys of 400 respondents. Data analysed using the Structural Equation Modelling (SEM) technique. The study found that website quality, website personality, and sales promotion influence the impulsive online purchases. Furthermore, website quality, website personality, and impulsive online buying have a simultaneous effect on e-satisfaction. Online travel agents are advised to pay more attention and improve website quality, website personality, and online impulsive buying as the predictor of e-satisfaction.
\end{abstract}

Keywords: digital media communication; online impulsive buying; e-satisfaction.

Received: August 28, 2020; Accepted: June 3, 2021; Published: October 31, 2021

*Corresponding author

Email: bethanisuryawardani@telkomuniversity.ac.id

To cite this document:

Suryawardani, B., Wulandari, A. \& Marcelino, D. (2021). Tourism 4.0: digital media communication on online impulse buying and e-satisfaction. BISMA (Bisnis dan Manajemen), 14(1), 74-93. https://doi.org/10.26740/bisma.v12n1.p7493.

\section{INTRODUCTION}

The tourist sector is now expanding in tandem with the era of globalization and the rapid growth of information technology. The growth of ICT (Information Communication and Technology) enables travellers to locate tourist sites by simply accessing tourist information on the internet. In our digital age, nearly all information 
is easily accessible through the internet. As a result, tourist locations worldwide must give complete information on their websites or other online media since it is one of the factors influencing tourist decisions (Buhalis, 2020).

The ICT global growth results effective communication practices and initiatives changes, including government and stakeholder policies in the tourist sector (Tiago et al., 2021). The internet is a reliable and successful marketing tool in the tourist industry. The internet may be utilized to disseminate information and communicate with travellers (Buhalis \& Law, 2008).

Tourism 4.0 is currently a tourism development trend in several countries worldwide. Many nations have planned for tourism 4.0 development. The development of tourism 4.0 is aims towards millennial visitors, who account for $50 \%$ of all incoming international tourists to Indonesia, with a predicted growth rate of 5\% (Puspita, 2019). The tourism 4.0 movement is defined by changes in visitor behaviour that are more independent and individual. Consumer behaviour is increasingly mobile, personal, and interactive, supported by the development of the digital era. In the tourism industry, changes in consumer behaviour are seen when the tourists search and share 70\% via digital platforms (Sugimoto et al., 2019).

According to Bloom Consulting's 2017-2018 Country Brand Ranking which describes branding of various nations, regions, and cities which comprises investment attractiveness, tourism attractiveness, talent attractiveness, reinforcement of excellence (increased public diplomacy activities), and export reinforcement, Indonesia was rated 11th in Asia and 35th in the world. It means that Indonesia is a promising tourism industry so digital advertising for tourist attractions becomes critical (Torres \& Vilar, 2019).

Based on Indonesian tourism data in 2018, the overall number of international tourists grew from 14.04 million in 2017 to 15.81 million with $59.75 \%$ of the rooms filled and the average duration of stay was 1.75 days. Based on these data, Indonesia remains a popular worldwide tourism destination (BPS, 2019).

Utama et al. (2020) stated that Indonesian e-tourism need to be optimized because the information provided on the tourism website was not interactive. Strategically, the organizations and destinations had to promote dialogue with various stakeholders actively. The internet has drastically altered how visitors connect, exchange opinions about their vacations, and interact with the tourism sector in general (Dwivedi \& Weerawardena, 2018).

The overall number of internet users has reached 143.3 million, or $54 \%$ of the Indonesian population (APJII, 2019). Most internet users in the age group 19-34 years were by $49.5 \%$. It shows that millennials are the largest internet user in Indonesia (Rosmayanti, 2019). However, the technological era is interesting for millennials as their attitudes, behaviour, and lifestyle differ from previous generations. Millennials also become an attractive target market for the business world. By identifying millennials, companies will be able to get business profits in the future (Moreno et al., 2017). 
One of digital marketing communication platform is website. Business websites should reflect or convey business aims, history, goods, and vision. The major issue in internet marketing communication is that businesses must build visually appealing and engaging sites to promote repeat visitors. Certain websites for mobile devices must be considered, as a daily social poll found that most Indonesians use smartphones to access online travel agencies, with an estimated 83.59\% using smartphones to access online travel agents (Zebua, 2018).

Online clients are in a psychological state distinct from unexpected and abrupt behaviour throughout the purchasing decision process, making it is challenging for businesses to forecast (Floh \& Madlberger, 2013; Chan et al., 2017). Online customers are website visitors who make their purchase decisions online processes, starting with browsing for product-related information and ending with tracking product shipments and completing payment transactions. As a result, two important criteria for impulsive online consumers are website technology usage and confidence in online businesses (Wu, 2013; Kusmaharani \& Halim, 2020).

Furthermore, website features might impact client browsing behaviour, which leads to purchasing or buying habits (Turkyilmaz et al., 2015). Emotional and instructive web content is often appropriate for online tourism items. Its presentation on the website is critical information for optimizing online browsing (Mohseni et al., 2018). By referring to prior research on website quality, website personality, and sales promotion on online impulsive purchasing and e-satisfaction (Widagdo \& Roz, 2021; Mohseni et al., 2018; Turkyilmaz et al., 2015), this study attempts to fill some gaps in existing studies, especially discrepancies in research findings. There is no research in the context of digital media communication and online impulse buying in a comprehensive manner that impacts the e-satisfaction of millennial tourists.

The research aims to develop the conceptual theory to create online consumer satisfaction, especially for millennial tourists in Indonesia. In addition, this study aims to find out how to increase online consumer satisfaction, especially by creating effective digital media communication to promote millennial travellers' internet impulsive purchases. The theoretical contribution of this study is improving tourism management science, especially about website quality, personality and sales promotion toward online impulsive buying and e-satisfaction. Academics might utilize the findings of this study as reference material for future research by developing theoretical and empirical models. In practice, the findings of this study may be used by online travel agent to simplify communication and advertising through digital media.

\section{Website Quality}

The available literature demonstrates several website features that might increase quality (Chan et al., 2017). Lemon \& Verhoef (2016) emphasized the importance of website design and content in attracting more online customers. The 
aesthetic attractiveness, transaction security, and navigation of a website are indicators that can directly influence the purchase of an impulsive consumer (Wells et al., 2011; Chan et al., 2017).

\section{Website Personality}

The personality dimensions of the website include enthusiasm, sophistication, discomfort, authenticity, and solidity to examine the website's personality (Davies et al., 2018). An enthusiastic website efficiently has structure and design that create a polite and pleasant ambience for visitors. However, the website's solidity relates to the amount to which its company operates professionally. The dependability and security of a website's personality are related to its authenticity, whilst sophistication refers to a stylish, classy, and upmarket (Poddar et al., 2009).

\section{Sales Promotion}

As a collection of various motivating methods, sales promotion is intended to encourage consumers to acquire a variety of items or services in a short period. Sales promotion aims to excite consumer demands and persuade people to buy items from certain companies right away (Kotler \& Keller, 2016). Stimulation of sales promotions is a significant antecedent of consumer online impulsive buying. Discounts, promotional activities, bundling, and purchasing ideas are examples of sales promotion stimuli that might drive customers to buy impulsively (Badgaiyan \& Verma, 2015; Dawson \& Kim, 2010).

\section{Online Impulsive Buying}

According to Sundström et al. (2019), the impulsive purchase is defined as sudden, exciting, and hedonic consumer activity, especially when they are uninformed. People typically make accidental and quick purchases (Iyer et al., 2020). Nevertheless, their intents may be connected to the website's ease or participation (Wu et al., 2016). According to Sharma et al. (2010), consumer emotions, inadequate cognitive control, or impulsive conduct drive online purchases. They contended that appealing things influence customer purchasing behaviour, causing people to make purchases without contemplating online transactions' financial and other repercussions.

\section{E-Satisfaction}

According to Anderson \& Srinivasan (2003), e-customer satisfaction can be described as sincerity from the customer in connection with the previous purchase experience. Meanwhile, Szymanski \& Henard (2001) stated that e-customer satisfaction is conceptualized as an assessment of experiences using the internet compared to their experiences in traditional ways relating to customers. E-customer satisfaction refers to customer satisfaction to the prior purchasing experience on a website (Hur et al., 2011). 


\section{Website Quality on Online Impulsive Buying}

Some research has found that the quality of website characteristics has a substantial effect on customers' online impulsive purchase behaviour. Turkyilmaz et al. (2015) observed, for example, that three characteristics of website quality, including entertainment, simplicity of use, and usability, had a positive impact on customers' online impulsive purchases. A well-designed interface improves the likelihood of spontaneous purchases by customers (Hasan, 2016). Turkyilmaz et al. (2015) shown that online merchants that wish to grow and keep their customer base must prioritize and improve the quality of their website. Clemes et al. (2014) investigated Chinese consumer behaviour and discovered that well-designed website components influenced online shopping uptake significantly. Based on the literature and prior study findings, the hypothesis is presented as follow.

H1: Website quality has a favourable impact to online impulsive buying.

\section{Website Personality on Online Impulsive Buying}

Turkyilmaz et al. (2015) studied and confirmed that website personality influences online impulsive purchase in a recent study. Similarly, the ease of use and enjoyment of the website will impact impulsive purchase behaviour. Chen et al. (2013) shows that impulsive purchasing which implies unexpected purchases, non-economic aims like excitement, inventiveness, and emotional or social enjoyment. Rezaei et al. (2016) found a link between web site personality features and online purchasers' impulsive purchasing behaviour. This means that while web surfing, customers are more likely to make impulse purchases depending on web site personality features such as sophistication and/or sincerity. Based on the literature and prior study findings, the hypothesis is presented as follow.

$\mathrm{H} 2$ : Website personality has a favourable impact to online impulsive buying.

\section{Sales Promotion on Online Impulsive Buying}

The simulation of sales advertising and the design elements of an online business is essential antecedents for impulsive online purchase. Sales, promotions, suggestions, and purchasing ideas are examples of stimuli that might convince customers to buy on the spur of the moment (Lo et al., 2016). Behera et al. (2020) have proposed that the stimulation of e-retailer sales promotions is connected to online customers' impulsive purchases. Online shoppers' impulsive purchasing behaviour is positively influenced by sales promotion (Badgaiyan \& Verma, 2015). Based on the literature and prior study findings, the hypothesis is presented as follow.

H3: Sales promotion has a favourable impact to online impulsive buying

\section{Online Impulsive Buying on E-Satisfaction}

Sharma et al. (2010) contended that appealing items motivate customer purchasing behaviour, leading to their delight in making purchases without contemplating the implications of online transactions. Furthermore, because 
acquiring tourism items is a high-satisfaction engagement activity, it necessitates planning (Ulker-Demire \& Giftci, 2020). It demonstrates that the level of pleasure with tourist items purchased spontaneously improves, but there will be limited understanding about the causes of spontaneous tourism product purchases (Laesser \& Dolnicar, 2012). Based on the literature and prior study findings, the hypothesis is presented as follow.

H4: Online impulsive buying has a favourable impact to e-satisfaction.

\section{Website Quality on E-Satisfaction}

Website design can be good if it has a stable operating system, a method for fast mistake recovery, and increased the worth of enjoyment gained by website users (Kim et al., 2017). A website with high aesthetic appeal may also create a lasting sense of satisfaction for tourists, enhance tourists' perceptions of business trustworthiness, and increase the frequency of tourist visits to the website (Wijiutami \& Octavia, 2017; Chou et al., 2015). Based on the literature and prior study findings, the hypothesis is presented as follow.

H5: Website quality has a favourable impact to e-satisfaction.

\section{Website Personality on E-Satisfaction}

An excellent website offers intriguing design or an easy purchasing experience. Furthermore, the many aspects of website personality, such as atmospheric signals, design, usability, and privacy, influence online visitor pleasure (Park et al., 2012; Wu et al., 2015). Based on Akrimi \& Khemakhem (2014) research, show a favourable influence of website personality on customer satisfaction, the effect of website personality on satisfaction of user behavioural reactions may be investigated. To the best of our knowledge, Louis \& Lombart (2010) have yet to experimentally investigate the relationship between website personality and user satisfaction. Based on the literature and prior study findings, the hypothesis is presented as follow. Furthermore, the relationship of all variables is illustrated in Figure 1.

H6: Website personality has a favourable impact to e-satisfaction.

\section{METHODS}

This study is part of a descriptive verification investigation that takes a quantitative approach. In this investigation, the interval scale was utilized as a measuring scale. The Likert scale employed in this sort of study had four evaluation points: strongly disagree (1), disagree (2), agree (3), and strongly agree (4) to predict more accurate findings.

Primary data was collected in this study. This study's population consisted entirely of millennials from Indonesia who had utilized internet travel agencies. A non-probability sampling method was utilized in this investigation. This data was gathered by distributing questionnaires to 400 Indonesian millennials (both online 
and offline) who had used an online travel agency based on Bernoulli formula (Zikmund et al., 2013), with a 5\% error rate.

Researchers used SEM to describe the relationship between all variables, as well as this research model include an intervening variable. The problem will then get more complicated since it will require some regression equations to be solved. As a result, it requires more extensive analytical procedures. SmartPLS 3.2.9 software was used for testing.

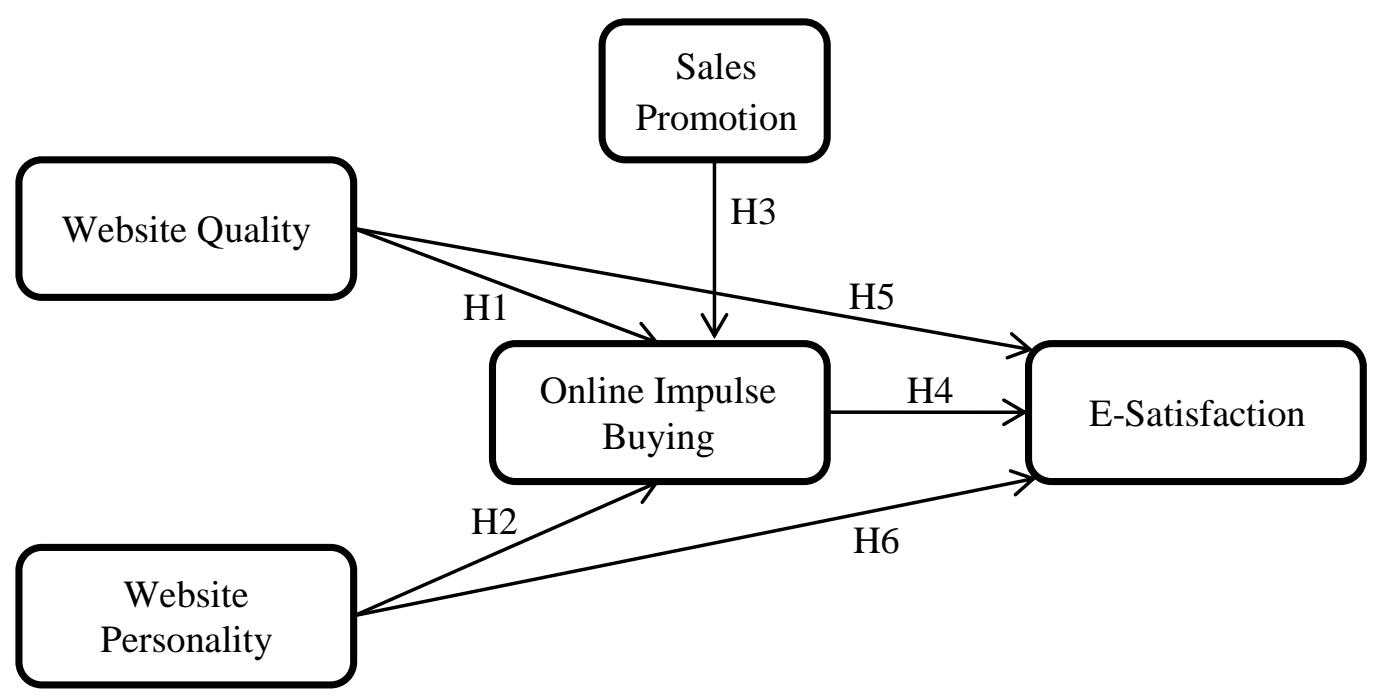

Figure 1. Conceptual Framework

\section{RESULTS AND DISCUSSION}

\section{The Result of Outer Model Testing}

The outer model is used to specify the connection between every indicator of the variables. While evaluating the outer model, verifying the accuracy and dependability of the indicators utilized is essential. Figure 2 depicts the outer model used in this investigation. There are two sorts of validity tests that may be performed, discriminant and convergent validity. If the loading factor value for each indicator is more than 0.5 , the convergent validity is fulfilled. The discriminant test is valid if the loading factor of a resultant variable indicator has the greatest value. Convergent validity testing results for each indicator are shown in Table 1.

According to Table 1, all indicators were legitimate since the loading factor was more than 0.5 . As a result, all the indicators employed in this study satisfied the convergent validity criteria, indicating that they are all valid. The results of the discriminant validity test on all research indicators are shown in Appendix 1.

The discriminant validity is determined by variables or indicators which have distinct values. If variables or indicators are solely connected to the variables or indicators themselves rather than variables or indicators that are not expected or represented. All indicators were valid, as presented in Appendix 1. It was carried out by analysing of the loading factor value on each variable indicator. The indicator is regarded legitimate if the loading factor value produced is greater than the loading 
factor on other variables. Based on these findings, it is possible to infer that there are no issues of discrimination. When compared to the correlation coefficient values for indicators in the constructing block in other columns, all indicators have a higher correlation coefficient with each construct.

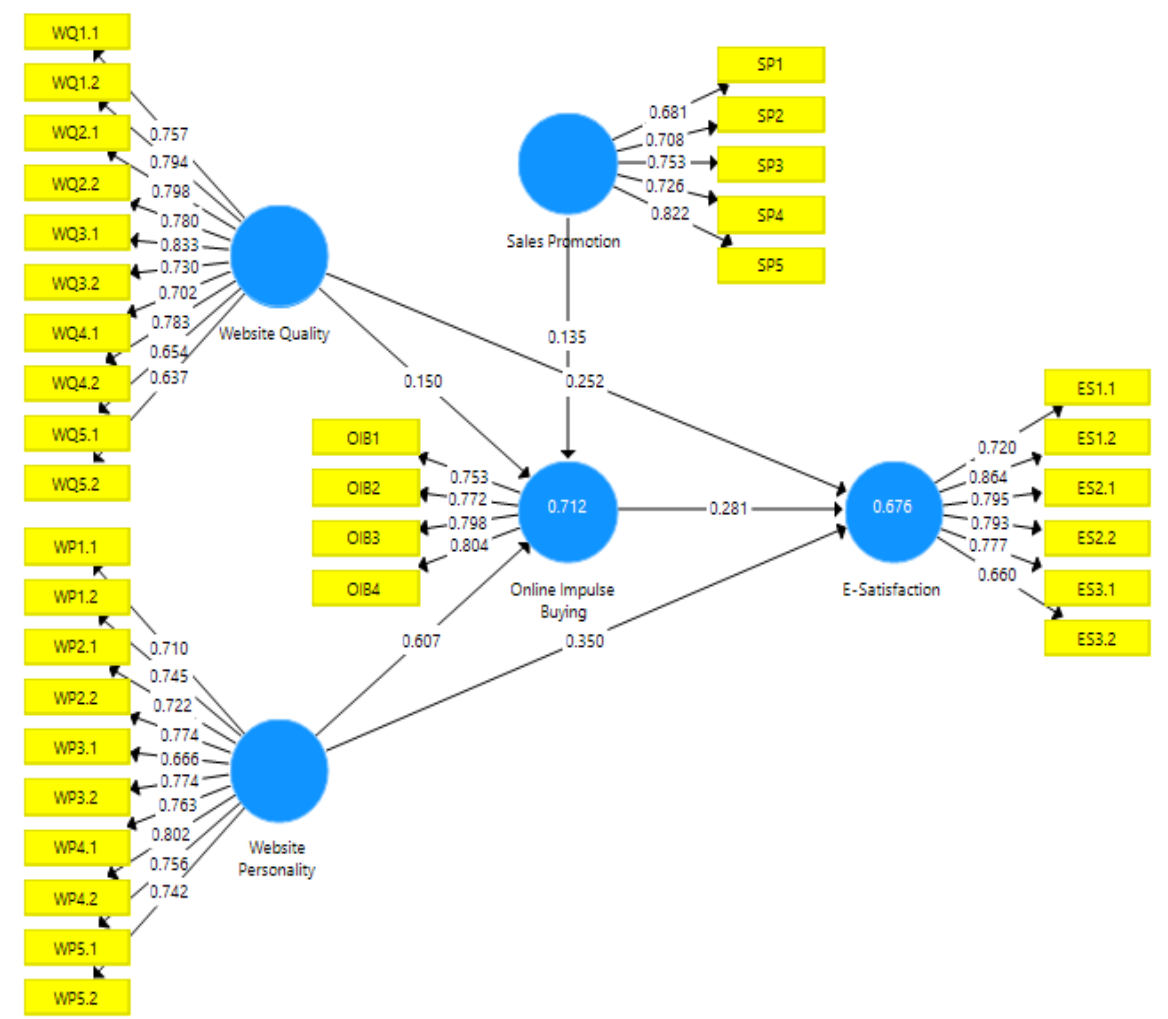

Figure 2. SEM Outer Model

Validity test was carried out by comparing the composite reliability and Cronbach's alpha values in each variable. The Cronbach's alpha value must be exceeded to be considered trustworthy or more than 0.7. According to Appendix 2, all variables included are reliable.

\section{The Result of Inner Model Testing}

The inner model test was run to determine the link among the research model's concept, significant value, and $\mathrm{R}^{2}$. It was processed by applying the $\mathrm{R}^{2}$ value in endogenous latent variables and the $t$-values of each external latent variable to the endogenous latent variable's bootstrapping result. The last step was to determine whether the independent and dependent variables were linked significantly and closely. Figure 3 depicts the t-values of each external latent variable to the endogenous latent variable. A two-tail test with a 5\% error level was used to carry out this test. As a result, the crucial value in the hypothesis test is 1.96 (Ghozali \& Latan, 2015). If the t-value is larger than the critical value (1.96), the effect of exogenous to endogenous latent variables is substantial. Table 2 shows hypothesis or t-test result. 
Table 1. Outer Loading Result

\begin{tabular}{|c|c|c|c|}
\hline Latent Variable & Influence (Effect) & Results & Information \\
\hline Website Quality & Usability1 — Website Quality & 0.757 & Valid \\
\hline \multirow[t]{9}{*}{ (WQ) } & Usability $2 \leftarrow$ Website Quality & 0.794 & Valid \\
\hline & Ease of use $1 \leftarrow$ Website Quality & 0.798 & Valid \\
\hline & Ease of use $2 \leftarrow$ Website Quality & 0.780 & Valid \\
\hline & Security $1 \leftarrow$ Website Quality & 0.833 & Valid \\
\hline & Security $2 \leftarrow$ Website Quality & 0.730 & Valid \\
\hline & Web Design1 — Website Quality & 0.702 & Valid \\
\hline & Web Design $2 \leftarrow$ Website Quality & 0.783 & Valid \\
\hline & Entertainment $1 \leftarrow$ Website Quality & 0.654 & Valid \\
\hline & Entertainment $2 \leftarrow$ Website Quality & 0.637 & Valid \\
\hline Website & Entusiasm $1 \leftarrow$ Website Personality & 0.710 & Valid \\
\hline \multirow[t]{9}{*}{ Personality (WP) } & Entusiasm $2 \leftarrow$ Website Personality & 0.745 & Valid \\
\hline & Solidity $1 \leftarrow$ Website Personality & 0.722 & Valid \\
\hline & Solidity $\leftarrow$ Website Personality & 0.774 & Valid \\
\hline & Genuine $1 \leftarrow$ Website Personality & 0.666 & Valid \\
\hline & Genuine $2 \leftarrow$ Website Personality & 0.774 & Valid \\
\hline & Sopisticated $1 \leftarrow$ Website Personality & 0.763 & Valid \\
\hline & Sopisticated $2 \leftarrow$ Website Personality & 0.802 & Valid \\
\hline & Unpleasant $1 \Leftarrow$ Website Personality & 0.756 & Valid \\
\hline & Unpleasant $2 \leftarrow$ Website Personality & 0.742 & Valid \\
\hline \multirow{5}{*}{$\begin{array}{l}\text { Sales Promotion } \\
\text { (SP) }\end{array}$} & Discount $\leftarrow$ Sales Promotion & 0.681 & Valid \\
\hline & Prize $\leftarrow$ Sales Promotion & 0.708 & Valid \\
\hline & Cashback $€$ Sales Promotion & 0.753 & Valid \\
\hline & Bundling $\leftarrow$ Sales Promotion & 0.726 & Valid \\
\hline & Purchase Idea $\leftarrow$ Sales Promotion & 0.822 & Valid \\
\hline Online Impulsive & Uniqueness $\leftarrow$ Online Impulsive Buy & 0.753 & Valid \\
\hline \multirow[t]{3}{*}{ Buying (OIB) } & Enjoyment $\leftarrow$ Online Impulsive Buy & 0.772 & Valid \\
\hline & Easy Access $€$ Online Impulsive Buy & 0.798 & Valid \\
\hline & Purchase $\leftarrow$ Online Impulsive Buy & 0.804 & Valid \\
\hline \multirow{6}{*}{$\begin{array}{l}\text { E-Satisfaction } \\
\text { (ES) }\end{array}$} & Purchase Intention $1 \leftarrow$ E-Satisfaction & 0.720 & Valid \\
\hline & Purchase Intention $2 \leftarrow$ E-Satisfaction & 0.864 & Valid \\
\hline & Positive E-WOM1 $€$ E-Satisfaction & 0.795 & Valid \\
\hline & Positive E-WOM $2 \leftarrow$ E-Satisfaction & 0.793 & Valid \\
\hline & Long Loyalty $1<$ E-Satisfaction & 0.777 & Valid \\
\hline & Long Loyalty $2 \leftarrow$ E-Satisfaction & 0.660 & Valid \\
\hline
\end{tabular}

Source: Data Processed

\section{The First SEM Sub-Structure}

The computation of the equation model from the first substructure is shown in the Appendix 3. This model includes three independent variables: website quality $\left(\mathrm{X}_{1}\right)$, website personality $\left(\mathrm{X}_{2}\right)$, and sales promotion $\left(\mathrm{X}_{3}\right)$, as well as one dependent variable, impulsive online purchase (Y). Appendix 3 shows objective information may be derived based on the analytical calculation result. The contribution of website quality $\left(\mathrm{X}_{1}\right)$, which directly impacts impulsive online purchase $(\mathrm{Y})$ is $2.25 \%$. The contribution of website personality $\left(\mathrm{X}_{2}\right)$, which directly impacts impulsive online purchase $(\mathrm{Y})$ is $36.84 \%$. The contribution of sales promotion $\left(\mathrm{X}_{3}\right)$, which directly impacts impulsive online purchase $(\mathrm{Y})$ is $1.82 \%$. The contribution of website quality $\left(\mathrm{X}_{1}\right)$, website personality $\left(\mathrm{X}_{2}\right)$, and promotion $\left(\mathrm{X}_{3}\right)$ to impulsive online purchase (Y) is $71.20 \%$. Other factors that cannot be addressed in this study impacted the remaining $28.80 \%$. 


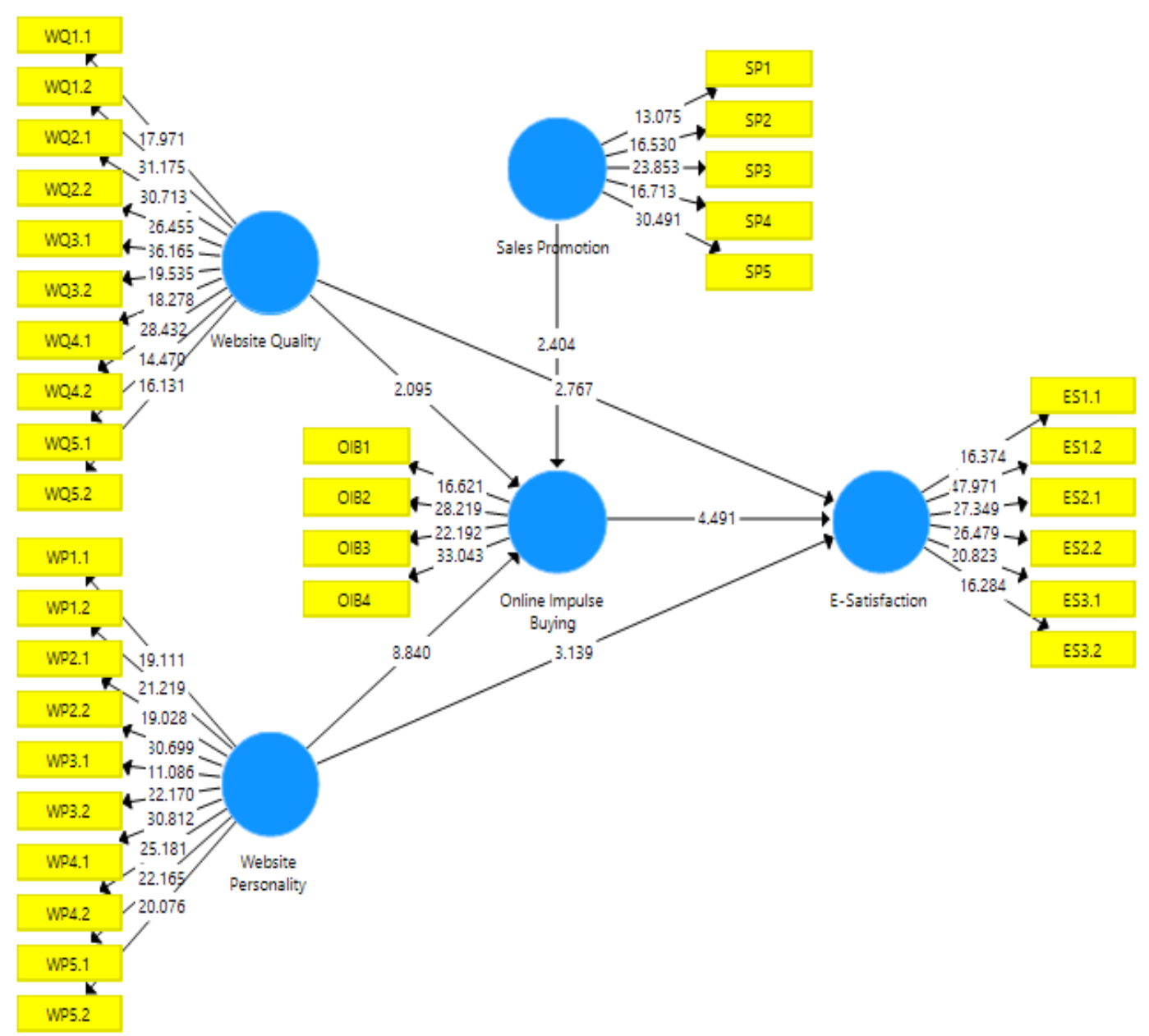

Figure 3. SEM Inner Model

\section{The Second SEM Sub-Structure}

This model includes three independent variables: website quality $\left(\mathrm{X}_{1}\right)$, website personality $\left(\mathrm{X}_{2}\right)$, and sales promotion $\left(\mathrm{X}_{3}\right)$, as well as one dependent variable, e-satisfaction $(Z)$. The computation of the equation model from the second sub-structure is shown in the Appendix 4.

The following objective information may be obtained from the computation results. Website quality $\left(\mathrm{X}_{1}\right)$ has a $6.35 \%$ direct influence on e-satisfaction $(\mathrm{Z})$. Meanwhile, the indirect impact of website quality $\left(X_{1}\right)$ on e-satisfaction $(Z)$ via impulsive online purchasing (Y) is $4.22 \%$. The percentage contribution of website personality $\left(\mathrm{X}_{2}\right)$ to e-satisfaction $(\mathrm{Z})$ is $12.25 \%$. In contrast, the indirect effect of website personality $\left(\mathrm{X}_{2}\right)$ on e-satisfaction $(\mathrm{Z})$ through impulsive online purchasing $(\mathrm{Y})$ is $17.06 \%$. Impulsive online purchase $(\mathrm{Y})$, which directly impacts e-satisfaction $(\mathrm{Z})$, contributed $7.90 \%$. Meanwhile, the contribution of website quality $\left(\mathrm{X}_{1}\right)$, Website Personality $\left(\mathrm{X}_{2}\right)$, and online impulsive buying $(\mathrm{Y})$ to e-satisfaction is $67.60 \%$. Other unknown factors impacted the remaining $32.40 \%$, which cannot be explained in this study. 
Table 2. Hypothesis or t-Test Result

\begin{tabular}{|c|c|c|c|c|}
\hline Variable Relationship & $t$ count & $\begin{array}{l}\text { Parameter } \\
\text { Coefficient }\end{array}$ & $\begin{array}{c}\text { Critical } \\
\text { Value }\end{array}$ & Result \\
\hline $\begin{array}{l}\text { Website Quality - Online } \\
\text { Impulsive Buying }\end{array}$ & 2.095 & 0.150 & 1.96 & $\begin{array}{l}\text { Ho rejected, H1 } \\
\text { accepted }\end{array}$ \\
\hline $\begin{array}{l}\text { Website Personality - Online } \\
\text { Impulsive Buying }\end{array}$ & 8.840 & 0.607 & 1.96 & $\begin{array}{l}\text { Ho rejected, } \mathrm{H} 2 \\
\text { accepted }\end{array}$ \\
\hline $\begin{array}{l}\text { Sales Promotion-Online } \\
\text { Impulsive Buying }\end{array}$ & 2.404 & 0.135 & 1.96 & $\begin{array}{l}\text { Ho rejected, H3 } \\
\text { accepted }\end{array}$ \\
\hline $\begin{array}{c}\text { Online Impulsive Buying - E- } \\
\text { Satisfaction }\end{array}$ & 4.491 & 0.281 & 1.96 & $\begin{array}{l}\text { Ho rejected, H4 } \\
\text { accepted }\end{array}$ \\
\hline $\begin{array}{l}\text { Website Quality - } \\
\text { E-Satisfaction }\end{array}$ & 2.767 & 0.252 & 1.96 & $\begin{array}{l}\text { Ho rejected, H5 } \\
\text { accepted }\end{array}$ \\
\hline $\begin{array}{c}\text { Website Personality - } \\
\text { E-Satisfaction }\end{array}$ & 3.139 & 0.350 & 1.96 & $\begin{array}{c}\text { Ho rejected, H6 } \\
\text { accepted }\end{array}$ \\
\hline
\end{tabular}

\section{Discussion}

The findings of this study indicate that there are several predictor factors in digital media communication that can increase online impulse buying and esatisfaction. The direct link between website quality and impulsive online purchasing was discovered, implying that website quality substantially influences online impulsive purchasing, and the quality of a website has a favourable influence on impulsive online purchasing. The study results are corroborated by the findings of a previous study performed by Turkyilmaz et al., (2015). It was found that three elements of web page quality (including entertainment, simplicity of use, and usability) positively impacted customers' online impulsive purchasing. The quality of online tourism websites are interfaces that allow interaction between tourism agents and millennial visitors. An excellent website design would include a reliable operating system and quick error recovery methods and methods to improve the value that travellers obtain from visiting the website. Furthermore, aesthetically beautiful websites may make an indelible impact on visitors, improve millennial perceptions of company trustworthiness, and boost the number of tourist visits to the website.

Website personality had a substantial impact on impulsive online purchasing, which indicating that the personality of a website has a favourable effect on online impulsive purchasing. Turkyilmaz et al. (2015) conducted a prior study that verified the website's personality influenced impulsive online purchases, which confirms the findings of this research. The convenience and enjoyment of website use will influence browser impulsive purchasing behaviour. A fun website does not have a distracting layout or an inconvenient purchasing process by having different features of a website reveal its personality. This study demonstrated that website characteristics influenced millennial travellers' online impulsive purchases. Similarly, several website characteristics, such as perceived simplicity of use and enjoyment, influence the millennial tourist browser's impulsive purchase behaviour. This result supports Chou et al. (2015) who stated that impulsive purchasing behaviour, defined as an unexpected choice to buy due to non-economic factors like 
excitement, imagination, or emotional or social delight, might cause consumers to buy impulsively.

The direct link between sales advertising and impulsive online purchase, it can be inferred that sales promotion had a substantial impact on impulsive online purchases. In other hand, sales promotion positively impacts impulsive online buying. This result supports findings of a previous study, which found that sales promotions might favourably affect customers' impulsive behaviour of online purchases (Badgaiyan \& Verma, 2015). Sales promotion aims to excite millennials' demands and compel them to purchase items from certain companies right away. Stimulation of sales promotion elements is a significant predictor of millennial visitors' online impulsive purchases. Sales promotion's stimuli, such as attractive discounts (e.g., price discount, clearances), promotions (e.g., buy-one-get-one-free, cash rebates, gifts), and bundling may all drive customers to spend impulsively.

Based on the direct link between online impulsive purchase and esatisfaction, it can be inferred that online impulsive purchase substantially affected e-satisfaction. It indicates that impulsive online buying has a positive impact on esatisfaction. A prior study by Sharma et al. (2010) found that customer purchasing behaviour influenced by appealing products will lead to their want to make purchases without thinking about the repercussions of internet purchasing. According to the result, attractive items affect millennia travellers' shopping behaviour, prompting them to encourage purchases without understanding the financial and other consequences of online purchases. This fact demonstrates that purchases of tourism items rise on their own. However, little is known about the factors that influence impulsive purchases of tourism items.

The direct link between website quality and e-satisfaction, implying that website quality had a significant impact on e-satisfaction, which indicating that website quality positively impacts e-satisfaction. This discovery is compatible with earlier research, which has found that a good website design with quick mistake recovery can improve visitors' value of satisfaction from visiting a website (Frias et al., 2008). This study demonstrates the significance of website design and content in attracting more online millennials tourist satisfaction. Whereas, online travel agencies wish to build and retain their customer base, they must emphasize and increase the quality of their website; otherwise, might result in customer loss.

Based on the direct link between personality website and e-satisfaction, consequently the website personality substantially affected e-satisfaction which indicating that the personality website has a positive impact on e-satisfaction. Previous studies that corroborate this finding were done by Park et al. (2012) and $\mathrm{Wu}$ et al. (2015), who found that distinct aspects of a website's personality influenced online visitor satisfaction. The authenticity of a website's personality relates to its dependability and security, whereas sophistication alludes to an elegant, sophisticated, and refined appearance or high-end website that improves the pleasure of millennial tourists. Different aspects of a website's personality, such 
as atmospheric signals, design, usability, and utilitarian privacy and security impact, are drivers of millennial tourist happiness.

\section{CONCLUSION}

According to the study findings, website quality, website personality, and sales promotion effect influence impulsive online purchase. Furthermore, the study findings revealed that website quality, website personality, and impulsive online purchase have a direct effect on e-satisfaction.

Based on the study's findings, the following recommendations can be made. The following researcher will be asked to include more factors to determine how digital communication media, especially website quality, website personality, and sales promotion, can influence impulsive online buying and how they impact esatisfaction. Meanwhile, online travel agents are advised to pay more attention and improve website quality and website personality. Based on the study results, these two variables positively influence online impulsive buying and e-satisfaction. Then, online travel brokers should preserve and improve the mediator variable, which is online impulse buying. The study findings revealed that the existence of this variable had a stronger influence on the e-satisfaction variable than the presence of the website quality and website personality variables.

This study is limited only to analysing how the digital media communication of online travel agents can influence online impulse buying and its impact on the esatisfaction of the millennial generation in Indonesia. There may be several other variables that could influence online impulse buying or e-satisfaction. Therefore, the researchers recommend that future research explore and analyse other variables. Then, because the subjects of this study were online travel agencies, the findings and conclusions may not apply to other sectors. As a result, it is strongly advised that more studies on this issue be conducted in other industries.

\section{REFERENCES}

Akrimi, Y., \& Khemakhem, P. R. (2014). An analysis of perceived usability, perceived interactivity and website personality and their effects on consumer satisfaction. International Journal of Management Excellence, 2(3), 227-236.

Anderson, R.E. and Srinivasan, S.S. (2003), E-satisfaction and e-loyalty: A contingency framework. Psychology \& Marketing, 20: 123138. https://doi.org/10.1002/mar.10063.

APJII. (2019). Profil Perilaku Pengguna Internet Indonesia. Jakarta: APJII \& Polling Indonesia. Retrieved July 14th 2020 from https://www.apjii.or.id/content/read/39/410/Hasil-Survei-Penetrasi-danPerilaku-Pengguna-Internet-Indonesia-2018.

Badgaiyan, A. J., \& Verma, A. (2015). Does urge to buy impulsively differ from impulsive buying behaviour? Assessing the impact of situational 
factors. Journal of Retailing and Consumer Services, 22, 145-157. https://doi.org/10.1016/j.jretconser.2014.10.002.

Behera, R. K., Gunasekaran, A., Gupta, S., Kamboj, S., \& Bala, P. K. (2020). Personalized digital marketing recommender engine. Journal of Retailing and Consumer $\quad$ Services, 53, 1-24. https://doi.org/10.1016/j.jretconser.2019.03.026.

BPS. (2019). Perkembangan Pariwisata Desember 2018. Jakarta: Berita Resmi Statistik No. 12/02/Th. XXII. Retrieved July 14th 2020 from https://www.bps.go.id/pressrelease/2019/02/01/1543/jumlah-kunjunganwisman-ke-indonesia-desember-2018-mencapai-1-41-juta-kunjungan.html.

Buhalis, D. (2020). Technology in tourism-from information communication technologies to eTourism and smart tourism towards ambient intelligence tourism: a perspective article. Tourism Review, 75(1), 267-272. https://doi.org/10.1108/TR-06-2019-0258.

Buhalis, D., \& Law, R. (2008). Progress in information technology and tourism management: 20 years on and 10 years after the Internet-The state of eTourism research. Tourism Management, 29(4), 609-623. https://doi.org/10.1016/j.tourman.2008.01.005.

Chan, T. K., Cheung, C. M., \& Lee, Z. W. (2017). The state of online impulsebuying research: A literature analysis. Information \& Management, 54(2), 204-217. https://doi.org/10.1016/j.im.2016.06.001.

Chen, C. Y., Lin, Y. H., \& Chang, W. M. (2013). Impulsive purchasing behavior for professional sports team-licensed merchandise-from the perspective of group effects. Sport Marketing Quarterly, 22(2), 83-91.

Chou, S., Chen, C. W., \& Lin, J. Y. (2015). Female online shoppers: Examining the mediating roles of e-satisfaction and e-trust on e-loyalty development. Internet Research, 25(4), 542-561. https://doi.org/10.1108/IntR-01-2014-0006.

Clemes, M. D., Gan, C., \& Zhang, J. (2014). An empirical analysis of online shopping adoption in Beijing, China. Journal of Retailing and Consumer Services, 21(3), 364-375. https://doi.org/10.1016/j.jretconser.2013.08.003.

Davies, G., Rojas-Mendez, J. I., Whelan, S., Mete, M., \& Loo, T. (2018). Brand personality: theory and dimensionality. Journal of Product and Brand Management, 27(2), 115-127. https://doi.org/10.1108/JPBM-06-2017-1499.

Dawson, S., \& Kim, M. (2010). Cues on apparel web sites that trigger impulse purchases. Journal of Fashion Marketing and Management, 14(2), 230-246. https://doi.org/10.1108/13612021011046084. 
Dwivedi, A., \& Weerawardena, J. (2018). Conceptualizing and operationalizing the social entrepreneurship construct. Journal of Business Research, 86, 32-40. https://doi.org/10.1016/j.jbusres.2018.01.053.

Floh, A., \& Madlberger, M. (2013). The role of atmospheric cues in online impulsebuying behavior. Electronic Commerce Research and Applications, 12(6), 425-439. https://doi.org/10.1016/j.elerap.2013.06.001.

Frias, D. M., Rodriguez, M. A., \& Castañeda, J. A. (2008). Internet vs. travel agencies on pre-visit destination image formation: An information processing view. Tourism Management, 29(1), 163-179. https://doi.org/10.1016/j.tourman.2007.02.020.

Ghozali, I., \& Latan, H. (2015). Konsep, Teknik, Aplikasi Menggunakan Smart PLS 3.0 Untuk Penelitian Empiris. BP Undip. Semarang.

Hasan, B. (2016). Perceived irritation in online shopping: The impact of website design characteristics. Computers in Human Behavior, 54, 224-230. https://doi.org/10.1016/j.chb.2015.07.056.

Hur, Youngjin \& Ko, Yong Jae \& Valacich, Joseph. (2011). A Structural Model of the Relationships Between Sport Website Quality, E-Satisfaction, and ELoyalty. Journal of Sport Management. 25. 458-473. https://doi.org/10.1123/jsm.25.5.458.

Iyer, G. R., Blut, M., Xiao, S. H., \& Grewal, D. (2020). Impulse buying: a metaanalytic review. Journal of the Academy of Marketing Science, 48(3), 384404. https://doi.org/10.1007/s11747-019-00670-w.

Kim, S. E., Lee, K. Y., Shin, S. I., \& Yang, S. B. (2017). Effects of tourism information quality in social media on destination image formation: The case of Sina Weibo. Information \& management, 54(6), 687-702. https://doi.org/10.1016/j.im.2017.02.009.

Kotler, P., \& Keller, K. L. (2016). A framework for marketing management. Boston, MA: Pearson.

Kusmaharani, A. S., \& Halim, R. E. (2020). Social influence and online impulse buying of Indonesian indie cosmetic products. Jurnal Ilmiah Manajemen, 10(2), 237-248. https://dx.doi.org/10.22441/mix.2020.v10i2.007.

Laesser, C., \& Dolnicar, S. (2012). Impulse purchasing in tourism-learnings from a study in a matured market. Anatolia, 23(2), 268-286. https://doi.org/10.1080/13032917.2012.688409.

Lemon, K. N., \& Verhoef, P. C. (2016). Understanding customer experience throughout the customer journey. Journal of Marketing, 80(6), 69-96. https://doi.org/10.1509/jm.15.0420. 
Lo, L. Y. S., Lin, S. W., \& Hsu, L. Y. (2016). Motivation for online impulse buying: A two-factor theory perspective. International Journal of Information Management, 36(5), 759-772. https://doi.org/10.1016/j.ijinfomgt.2016.04.012.

Louis, D., \& Lombart, C. (2010). Impact of brand personality on three major relational consequences (trust, attachment, and commitment to the brand). Journal of Product \& Brand Management, 19(2), 114-130. https://doi.org/10.1108/10610421011033467.

Mohseni, S., Jayashree, S., Rezaei, S., Kasim, A., \& Okumus, F. (2018). Attracting tourists to travel companies' websites: the structural relationship between website brand, personal value, shopping experience, perceived risk and purchase intention. Current Issues in Tourism,21(6), 616-645. https://doi.org/10.1080/13683500.2016.1200539.

Moreno, F. M., Lafuente, J. G., Carreón, F. Á., \& Moreno, S. M. (2017). The characterization of the millennials and their buying behavior. International Journal of Marketing Studies, 9(5), 135-144. https://doi.org/10.5539/ijms.v9n5p135.

Park, E. J., Kim, E. Y., Funches, V. M., \& Foxx, W. (2012). Apparel product attributes, web browsing, and e-impulse buying on shopping websites. Journal of Business Research,65(11), 1583-1589. https://doi.org/10.1016/j.jbusres.2011.02.043.

Poddar, A., Donthu, N., \& Wei, Y. (2009). Web site customer orientations, Web site quality, and purchase intentions: The role of Web site personality. Journal of Business Research. 62 (4). 441-450. https://doi.org/10.1016/j.jbusres.2008.01.036.

Puspita, S. (2019). Tourism 4.0 Jadi Tren Pengembangan Pariwisata Dunia. Retrieved July 14th, 2020, from https://travel.kompas.com/read/2019/03/01/070000127/tourism-4.0-jaditren-pengembangan-pariwisata-dunia.

Rezaei, S., Ali, F., Amin, M., \& Jayashree, S. (2016). Online impulse buying of tourism products: The role of web site personality, utilitarian and hedonic web browsing. Journal of Hospitality and Tourism Technology, 7(1), 60-83. https://doi.org/10.1108/JHTT-03-2015-0018.

Rosmayanti. (2019). 104 Perusahaan Pemenang Millenials Top Brand Award 2019. Retrieved July 14th, 2020, from https://www.wartaekonomi.co.id/read213014/104-perusahaan-pemenangmillenials-top-brand-award-2019.html.

Sharma, P., Sivakumaran, B., \& Marshall, R. (2010). Exploring impulse buying and variety seeking by retail shoppers: towards a common conceptual 
framework. Journal of Marketing Management, 26(5-6), 473-494. https://doi.org/10.1080/02672570903485097.

Sugimoto, K., Ota, K., \& Suzuki, S. (2019). Visitor mobility and spatial structure in a local urban tourism destination: GPS tracking and network analysis. Sustainability, 11(3), 919. https://doi.org/10.3390/su11030919.

Sundström, M., Hjelm-Lidholm, S., \& Radon, A. (2019). Clicking the boredom away-Exploring impulse fashion buying behavior online. Journal of Retailing and Consumer Services, 47, 150-156. https://doi.org/10.1016/j.jretconser.2018.11.006.

Szymanski, D.M. and Henard, D.H. (2001) Customer Satisfaction: A MetaAnalysis of the Empirical Evidence. Journal of the Academy of Marketing Science, 29, 16-35.

Tiago, F., Gil, A., Stemberger, S., \& Borges-Tiago, T. (2021). Digital sustainability communication in tourism. Journal of Innovation \& Knowledge, 6(1), 27-34. https://doi.org/10.1016/j.jik.2019.12.002.

Torres, J. F., \& Vilar, G. (2019). 6th edition of the Bloom Consulting Country Brand Ranking 2019-2020 Tourism Edition. Spain: Bloom Consulting.

Turkyilmaz, C. A., Erdem, S., \& Uslu, A. (2015). The effects of personality traits and website quality on online impulse buying. Procedia - Social and Behavioral Sciences, $175, \quad 98-105$. https://doi.org/10.1016/j.sbspro.2015.01.1179.

Ulker-Demirel, E., \& Ciftci, G. (2020). A systematic literature review of the theory of planned behavior in tourism, leisure and hospitality management research. Journal of Hospitality and Tourism Management, 43, 209-219. https://doi.org/10.1016/j.jhtm.2020.04.003.

Utama, R., Bagus, I. G., Ruspendi Junaedi, I. W., Krismawintari, D., Putu, N., Pramono, J., \& Laba, I. N. (2020). New Normal Acceleration Strategy for Bali Tourism Destination Recovery with E-Tourism and Special Health Protocol for the Tourism Sector. Technium Soc. Sci. J., 10(1), 156-166. https://doi.org/10.47577/tssj.v10i1.1332.

Wells, J. D., Parboteeah, V., \& Valacich, J. S. (2011). Online impulse buying: understanding the interplay between consumer impulsiveness and website quality. Journal of the Association for Information Systems, 12(1), 32-56. https://doi.org/10.17705/1jais.00254.

Widagdo, B., \& Roz, K. (2021). Hedonic Shopping Motivation and Impulse Buying: The Effect of Website Quality on Customer Satisfaction. The Journal of Asian Finance, Economics, and Business, 8(1), 395-405. https://doi.org/10.13106/jafeb.2021.vol8.no1.395. 
Wijiutami, S. S., \& Octavia, D. (2017). Pengaruh E-service Quality Terhadap Esatisfaction Serta Dampaknya Pada E-loyalty Pelanggan E-commerce C2c Di Kota Jakarta Dan Bandung. eProceedings of Management, 4(3), 2212-2220. https://openlibrarypublications.telkomuniversity.ac.id/index.php/manageme nt/article/view/4892.

Wu, K., Vassileva, J., Noorian, Z., \& Zhao, Y. (2015). How do you feel when you see a list of prices? The interplay among price dispersion, perceived risk and initial trust in Chinese C2C market. Journal of Retailing and Consumer Services, 25, 36-46. https://doi.org/10.1016/j.jretconser.2015.03.007.

$\mathrm{Wu}, \mathrm{L}$. (2013). The antecedents of customer satisfaction and its link to complaint intentions in online shopping: An integration of justice, technology, and trust. International Journal of Information Management, 33(1), 166-176. https://doi.org/10.1016/j.ijinfomgt.2012.09.001.

Wu, L., Chen, K. W., \& Chiu, M. L. (2016). Defining key drivers of online impulse purchasing: A perspective of both impulse shoppers and system users. International Journal of Information Management, 36(3), 284-296. https://doi.org/10.1016/j.ijinfomgt.2015.11.015.

Wu, L., Li, J. Y., \& Fu, C. Y. (2011). The adoption of mobile healthcare by hospital's professionals: An integrative perspective. Decision support systems, 51(3), 587-596. https://doi.org/10.1016/j.dss.2011.03.003.

Zebua, F. (2018). Retrieved July 14th 2020 from https://dailysocial.id/post/laporandailysocial-survey-online-travel-agencies-ota-2018.

Zikmund, W. G., Carr, J. C., \& Griffin, M. (2013). Business Research Methods (Book Only). South-Western: Cengage Learning.

Appendix 1. Cross Loading Result

\begin{tabular}{ccccccc}
\hline Indicator & WQ & WP & SP & OIB & ES & Result \\
\hline Usability1 & 0.757 & 0.301 & 0.457 & 0.369 & 0.490 & Valid \\
Usability2 & 0.794 & 0.409 & 0.471 & 0.400 & 0.372 & Valid \\
Ease of use1 & 0.798 & 0.493 & 0.364 & 0.309 & 0.469 & Valid \\
Ease of use2 & 0.780 & 0.249 & 0.381 & 0.325 & 0.406 & Valid \\
Security1 & 0.833 & 0.470 & 0.313 & 0.488 & 0.322 & Valid \\
Security2 & 0.730 & 0.343 & 0.358 & 0.481 & 0.403 & Valid \\
Web Design1 & 0.702 & 0.485 & 0.425 & 0.439 & 0.406 & Valid \\
Web Design2 & 0.783 & 0.477 & 0.416 & 0.441 & 0.355 & Valid \\
Entertainment1 & 0.654 & 0.378 & 0.341 & 0.348 & 0.453 & Valid \\
Entertainment2 & 0.637 & 0.335 & 0.445 & 0.491 & 0.444 & Valid \\
Entusiasm1 & 0.449 & 0.710 & 0.391 & 0.317 & 0.437 & Valid \\
Entusiasm2 & 0.405 & 0.745 & 0.498 & 0.425 & 0.474 & Valid \\
Solidity1 & 0.460 & 0.722 & 0.391 & 0.245 & 0.434 & Valid \\
Solidity2 & 0.355 & 0.774 & 0.421 & 0.418 & 0.475 & Valid \\
Genuine1 & 0.343 & 0.666 & 0.430 & 0.484 & 0.481 & Valid \\
Genuine2 & 0.433 & 0.774 & 0.494 & 0.444 & 0.330 & Valid \\
Sopisticated1 & 0.460 & 0.763 & 0.347 & 0.325 & 0.447 & Valid \\
Sopisticated2 & 0.395 & 0.802 & 0.416 & 0.442 & 0.462 & Valid \\
Unpleasant1 & 0.398 & 0.756 & 0.475 & 0.429 & 0.403 & Valid \\
\hline
\end{tabular}




\begin{tabular}{ccccccc}
\hline Indicator & WQ & WP & SP & OIB & ES & Result \\
\hline Unpleasant2 & 0.464 & 0.742 & 0.480 & 0.440 & 0.310 & Valid \\
Discount & 0.460 & 0.473 & 0.681 & 0.497 & 0.461 & Valid \\
Prize & 0.365 & 0.400 & 0.708 & 0.317 & 0.497 & Valid \\
Cashback & 0.429 & 0.302 & 0.753 & 0.342 & 0.444 & Valid \\
Bundling & 0.388 & 0.361 & 0.726 & 0.342 & 0.294 & Valid \\
Purchase Idea & 0.471 & 0.412 & 0.822 & 0.322 & 0.447 & Valid \\
Uniqueness & 0.455 & 0.469 & 0.473 & 0.753 & 0.486 & Valid \\
Enjoyment & 0.431 & 0.480 & 0.352 & 0.772 & 0.350 & Valid \\
Easy Access & 0.355 & 0.352 & 0.421 & 0.798 & 0.384 & Valid \\
Purchase & 0.269 & 0.307 & 0.468 & 0.804 & 0.440 & Valid \\
Purchase Intention1 & 0.479 & 0.310 & 0.450 & 0.433 & 0.720 & Valid \\
Purchase Intention2 & 0.476 & 0.356 & 0.335 & 0.454 & 0.864 & Valid \\
Positive E-WOM1 & 0.323 & 0.440 & 0.361 & 0.359 & 0.795 & Valid \\
Positive E-WOM2 & 0.243 & 0.341 & 0.363 & 0.338 & 0.793 & Valid \\
Long Loyalty1 & 0.234 & 0.417 & 0.481 & 0.214 & 0.777 & Valid \\
Long Loyalty2 & 0.369 & 0.447 & 0.467 & 0.491 & 0.660 & Valid \\
\hline
\end{tabular}

Appendix 2. Reliability Test Result

\begin{tabular}{cccc}
\hline Latent Variable & Composite Reliability & Cronbach's Alpha & Result \\
\hline Website Quality & 0.927 & 0.912 & Reliable \\
Website Personality & 0.926 & 0.911 & Reliable \\
Sales Promotion & 0.857 & 0.791 & Reliable \\
Online Impulsive Buying & 0.863 & 0.788 & Reliable \\
E-Satisfaction & 0.897 & 0.862 & Reliable \\
\hline
\end{tabular}

Appendix 3. Calculate of First Sub-Structure Variables

\begin{tabular}{|c|c|c|c|c|c|c|}
\hline \multirow{2}{*}{ Variable } & \multirow{2}{*}{$\begin{array}{c}\text { Coefficie } \\
\text { nt }\end{array}$} & \multirow{2}{*}{ Through } & \multicolumn{3}{|c|}{ Influence (Effect) } & \multirow{2}{*}{$\begin{array}{c}\text { Simulta } \\
\text { neous }\end{array}$} \\
\hline & & & Direct & Indirect & Total & \\
\hline $\begin{array}{c}\text { Website } \\
\text { Quality }\left(\mathrm{X}_{1}\right)\end{array}$ & 0.150 & $\mathrm{X}_{1} \rightarrow \mathrm{Y}$ & $\begin{array}{c}0.150 \times 0.150 \times \\
100 \%=2.25 \%\end{array}$ & - & $2.25 \%$ & - \\
\hline $\begin{array}{c}\text { Website } \\
\text { Personality }\left(\mathrm{X}_{2}\right)\end{array}$ & 0.607 & $\mathrm{X}_{2} \rightarrow \mathrm{Y}$ & $\begin{array}{l}0.607 \times 0.607 \times \\
100 \%=36.84 \%\end{array}$ & - & $36.84 \%$ & - \\
\hline $\begin{array}{c}\text { Sales } \\
\text { Promotion }\left(\mathrm{X}_{3}\right)\end{array}$ & 0.135 & $\mathrm{X}_{3} \rightarrow \mathrm{Y}$ & $\begin{array}{c}0.135 \times 0.135 \times \\
100 \%=1.82 \%\end{array}$ & - & $1.82 \%$ & - \\
\hline Error 1 & $\begin{array}{l}1-0.7120 \\
=0.2880\end{array}$ & - & - & - & $28.80 \%$ & - \\
\hline $\begin{array}{l}\text { Website Quality } \\
\left(\mathrm{X}_{1}\right) \text {, Website } \\
\text { Personality }\left(\mathrm{X}_{2}\right) \text {, } \\
\text { Sales Promo }\left(\mathrm{X}_{3}\right)\end{array}$ & 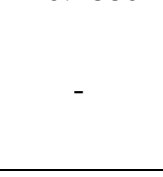 & - & - & - & - & $\begin{array}{l}0.712= \\
71.20 \%\end{array}$ \\
\hline
\end{tabular}

Apppendix 4. Calculate of Second Sub-Structure Variables

\begin{tabular}{|c|c|c|c|c|c|c|}
\hline \multirow{2}{*}{ Variable } & \multirow{2}{*}{$\begin{array}{c}\text { Coefficie } \\
\text { nt }\end{array}$} & \multirow{2}{*}{ Through } & \multicolumn{3}{|c|}{ Influence (Effect) } & \multirow{2}{*}{$\begin{array}{l}\text { Simult } \\
\text { aneous }\end{array}$} \\
\hline & & & Direct & Indirect & Total & \\
\hline $\begin{array}{c}\text { Website } \\
\text { Quality }\left(\mathrm{X}_{1}\right)\end{array}$ & 0.252 & $\begin{array}{l}\mathrm{X}_{1} \rightarrow \mathrm{Y} \\
\quad \rightarrow \mathrm{Z}\end{array}$ & $\begin{array}{c}0.252 \times 0.252 \times \\
100 \%=6.35 \%\end{array}$ & $\begin{array}{c}0.150 \times 0.281 \\
\times 100 \%= \\
4.22 \%\end{array}$ & $10.57 \%$ & - \\
\hline $\begin{array}{c}\text { Website } \\
\text { Personality } \\
\left(\mathrm{X}_{2}\right)\end{array}$ & 0.350 & $\begin{array}{l}\mathrm{X}_{2} \rightarrow \mathrm{Y} \\
\quad \rightarrow \mathrm{Z}\end{array}$ & $\begin{array}{l}0.350 \times 0.350 \times \\
100 \%=12.25 \%\end{array}$ & $\begin{array}{c}0.607 \times 0.281 \\
\times 100 \%= \\
17.06 \%\end{array}$ & $29.31 \%$ & - \\
\hline $\begin{array}{l}\text { Online } \\
\text { Impulsive } \\
\text { Buying (Y) }\end{array}$ & 0.281 & $\mathrm{Y} \rightarrow \mathrm{Z}$ & $\begin{array}{c}0.281 \times 0.281 \times \\
100 \%=7.90 \%\end{array}$ & - & $7.90 \%$ & - \\
\hline
\end{tabular}


Suryawardani, B., Wulandari, A. \& Marcelino, D.

Tourism 4.0: digital media communication on online impulse buying and e-satisfaction

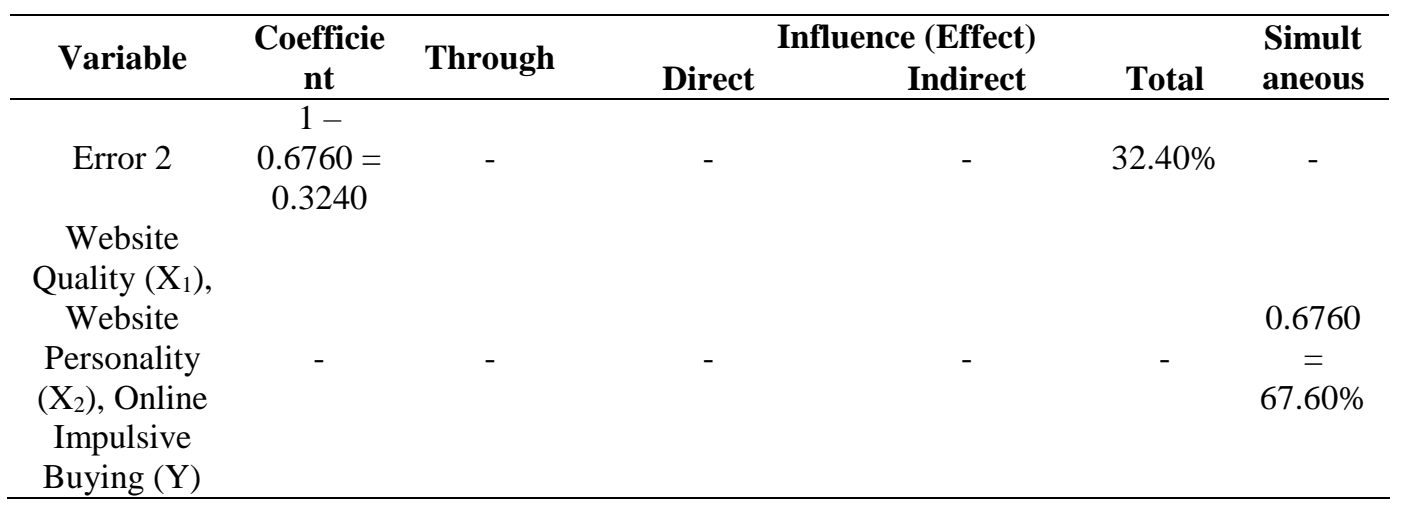

